\title{
RETHINKING EFFECTS OF INNOVATION IN COMPETITION IN THE ERA OF NEW DIGITAL TECHNOLOGIES *
}

\author{
Ana Pošćić ${ }^{* *}$ \\ Adrijana Martinović ${ }^{* * *}$
}

\begin{abstract}
The new technologies, digitalization, algorithms, big data, artificial intelligence are already changing our lives and commercial habits. The technological revolution with new products and services is transforming the market and business operators. There is a general understanding that new technological improvements benefit competition. The question is, whether competition models are adequate and ready to deal with the challenges associated with new technologies. In recent years, there has been a revived interest in the concept of innovation and its application in competition policy and law. However, proper examination of its influence on competition policy is lacking. During the last decades, there have been attempts to explain the relationship between competition and innovation by including various innovation models in competition analysis. The innovation instruments have developed. Despite these developments, there are still diametrically opposed theoretical approaches, from completely ignoring the concept of innovation in competition law to the ones that develop a specific economic test in competition analysis. This paper will try to analyze and compare different approaches to the intersection of competition and innovation. Systematic theories that assess innovation in the context of competition are scarce. Competition authorities have been focused on issues of consumer and social welfare, rather than on the impact of innovation on the competition.
\end{abstract}

This work has been fully supported by the University of Rijeka under the project uniri-drustv-18-252 "Legal aspects of the digital transformation of society".

** Ana Pošćić, University of Rijeka, Faculty of Law, Rijeka, Croatia; aposcic@pravri.hr.

**** Adrijana Martinović, University of Rijeka, Faculty of Law, Rijeka, Croatia; adrijana@ pravri.hr. 
The idea is to try to define the role of innovation in competition analysis. The question is whether competition law needs new tools in order to understand new developments and innovations.

The authors argue that competition has its own instruments that can be applied to new models with certain adaptations. Certain regulatory instruments are necessary, but they can be implemented without stifling innovation and the development of new technologies. The authors attempt to offer possible solutions for the existing challenges based on the state of art research. The challenges associated with the market definition and market power are explained. It is argued that competition analyses should acknowledge that innovation is essential for competition in the digital era.

KEYWORDS: innovation, competition law, digital era

\section{INTRODUCTION}

The technical revolution presents a new challenge to every aspect of society. Innovative services and products are transforming markets, their actors, as well as the way we live and communicate. Digitalization has brought numerous benefits to the usual manners of conducting business, along with certain risks. The rapid change affects the usual understanding of undistorted competition with many different actors involved. With the improvement of Internet technologies and the advances in artificial intelligence systems, the potentials have increased even more. Innovations lead to new social and business opportunities. Many potential benefits for European citizens and undertakings are on the rise, but some concerns have to be addressed too.

This paper aims to explore the implications of competition rules application. The authors shall examine the problem from multiple angles and perspectives. The main dilemma concerns the question of whether competition law with its existing tools is prepared to deal with new challenges posed by the digital revolution. It is necessary to realize how the legal framework has to be adapted and improved. It will be shown that the main issue concerns the flexibility of the current competition rules. Economic growth must be followed by a well developed competition policy. The main quandary is whether current competition rules are still adequate for the digital economy environment. Specifically, can we apply traditional competition concepts to new markets and actors?

During the years, we have experienced rapid evolution and adaptation of competition law to new challenges. The Report on competition policy ${ }^{1}$ tries to identify possible obstacles for competition in the changing environment. According to the Report, the basic principles enshrined in the Treaties can ensure

1 Crémer, J. et al: Competition policy for the digital era, final report, Luxembourg, 2019. 
consistent enforcement. ${ }^{2}$ However, special features of the digital economy deserve particular attention. Some traditional concepts will have to be improved. One of them is the definition of the relevant market and market deficiency that can be useful background for adjusting the existing legal framework. ${ }^{3}$

Innovation shapes consumer preferences, with lots of new products and high-skilled services on the market. ${ }^{4}$ Traditional competition assessment must be adapted to the new economic developments.

New digital markets with innovative products and services are not devoid of anti-competitive practices. However, they bring about new challenges from the aspect of competition regulation and enforcement. The idea is to shed some light on the implications of innovation in the digital transformation of competition.

\section{IS THERE A ROOM FOR INNOVATION IN COMPETITION ASSESSMENT?}

When we consider the ramifications of the digitalization of society, many new notions and processes emerge. It is sometimes difficult for legal scholars to fully comprehend all the complex technological features associated with digitalization. Therefore, the synergy between various disciplines and practitioners is necessary. The first goal of competition has always been consumer welfare. This is even more highlighted in the era of innovation and new technologies. A dynamic approach is necessary to adjust competition rules to new developments. We, therefore, agree with Cremer et al. that the application of existing rules with some modifications could be satisfactory. They stress that "the competition policy must be vigorous, disciplined and coherent. It must rely on solid analysis of the new market settings ... which will imply that "the invisible hand of the market" must be supplemented by "invisible hand of competition authorities or of the legislator."

The dilemma is about the direction of the development of competition law in the new digital era. The primary objectives ${ }^{6}$ ensuring undistorted compe-

\footnotetext{
$2 \quad$ Ibid., p. 3.

3 Ibid., p. 5.

4 On platform-enabled services see: Bodiroga-Vukobrat, N., Pošćić, A, Martinović, A.: “Old Economy" Restrictions in the Digital Market for Services, InterEuLawEast, V (2), 2018, pp. 169-188.

5 Ibid., p. 14.

6 See: Van den Bergh, R.: Comparative Competition Law and Economics, Cheltenham, 2017, p. 86.
} 
tition are still relevant, but slight modifications are needed. Digitalization is changing our society and economy and it is of utmost importance to integrate innovation concepts in the competition analysis.?

Innovation is defined as a notion that "encompasses the commercialization of newly invented or upgraded products (product innovation) or production and distribution process (process innovation)." ${ }^{8}$ Besides, some definitions look at the disruptive feature of innovation and ones that focused on the side effects of innovation to markets. ${ }^{9}$ In the end, the fact is that innovation affects the competitive process in a market, so it is not really important which definition we opt for.

There is a need for coordination and mutual understanding between different regimes. A lot has been said about innovation and competition separately, but there is a lack of comprehensive studies on the intersection and mutual influence between innovation and competition policy.

The imperative of ensuring a stable and competitive market brings interrelations between competition and innovation into focus. There are various methodologies proposed. We find Cleynenbreugel's approach, who says that his intention is not to propose progress in the relationship between those two disciplines, but just to help in understanding the position of innovation in the competition law analysis, the one that is most convincing. ${ }^{10}$ There is no uniform understanding of the extent to which competition law analysis should take into consideration the innovation argument in the analytical assessment. ${ }^{11}$ So far, the doctrine has been oriented on investigating whether innovation arguments can become part of the theory of harm, as the basic test in competition analysis. Cleynenbreugel summarizes different approaches under two opposed clusters. The first includes scholars who argue that the role of innovation in the competition is external. According to them, the competition law enforcers are focused on market structure and behavior. The innovation argument cannot be sustained in favor of anticompetitive restraints. Innovation is beyond any competition assessment. The innovation arguments are not perceived as crucial in the competition analysis. That is more or less the current position of the European Commission. The innovation principle is recognized only as a part of the competitive mar-

\footnotetext{
Competition policy for the digital era, p. 126.

8 Van Cleynenbreugel, P.: Innovation in competition law analysis: making sense of on-going academic and policy debates, in Nihoul, P., Van Cleynenbreugel, P. (eds.): The Roles of Innovation in Competition Law Analysis, Cheltenham, 2018, p. 3.

$9 \quad$ Ibid., p. 3.

10 Loc. cit.

$11 \quad$ Ibid., p. 6.
} 
ket environment. The anticompetitive enforcers have not developed the concept of innovation separately. The agencies have been focused on price effects and ignoring non-price parameters of competition as quality and innovation. Stucke speaks of the price king or price-centric approach. ${ }^{12}$ It is difficult to measure the impact on anticompetitive harm and dynamic efficiency.

The contrary view sees innovation as an integral part of the competition evaluation and obliges the enforcement agencies to incorporate innovation considerations directly into competition appraisal. In contrast to the first cluster, it sees innovation as a value to be called to justify or condemn certain undertaking's behavior. ${ }^{13}$ This position can be noticed in merger analysis where innovation is a benefit to be protected under the competition law analysis. Sometimes this approach is criticized because the test of "significant impediment to innovation" should be compatible with the existing competition framework. ${ }^{14}$ It seems that those opposing views differentiate between the external or internal role of innovation in competition.

The main fear is that competition law is stuck on the old dominance theories based on static concepts. The competition must foster a more dynamic approach in the terms of Schumpeterian competition. It means competition based on new products and new technologies. ${ }^{15}$ This concept has not evolved as much as Hayek's concept of "competition as a discovery procedure". ${ }^{16}$ The problem with this process is that it is too general with no clear grounds for how it should be applied in specific competition cases. Both concepts are focused on innovation. According to Kerber, there is no elaborated concept that describes the assessment of innovation in competition cases yet. ${ }^{17}$

Innovation has numerous benefits for society as a whole. The consumer gains new innovative products. In the high-tech industry, firms must innovate and search for new products to attract new users. On the other hand, without protection through intellectual property rights undertaking would lose incentives to innovate and invest in new technologies. The traditional enforcement has always been more focused on price increases and analyzing the market through possible market sharing and other anticompetitive conducts. The idea is to

12 Stucke, M. E., Grunes, A. P.: Big Data and Competition Policy, Oxford, 2016, p. 109 and 113.

13 Van Cleynenbreugel, P., op. cit., p. 8.

14 Ibid., p. 9.

15 Kerber,W.: Competition, Innovation and Competition Law: Dissecting the Interplay, in Gerard, D. et all. (eds.), Dynamic Markets, Dynamic Competition and Dynamic Enforcement, Bruxelles, 2018, p. 37.

16 Ibid., p. 38.

17 Loc. cit. 
include innovation in the possible anticompetitive assessment. Caution is necessary. Taking into consideration innovation in competition incorrectly may enhance the risk of possible mistakes. Too much focus on innovation processes can discourage future investments.

We argue that competition plays one of the essential roles in fostering innovation, but only in an open market. Therefore, innovation must become an essential element in every competition assessment.

\section{GOALS OF COMPETITION POLICY IN THE DIGITAL ERA}

The traditional goals of competition law have been focused on increasing competitiveness, better allocation of resources, and improved consumer choices. Traditionally, economists have relied on the model of social or total welfare, for which it is irrelevant whether the benefits are realized by consumers or producers. EU competition law does not treat consumer's and producer's welfare alike. Consumer welfare is valued more highly than producer welfare. Numerous provisions substantiate this conclusion. ${ }^{18}$

We can ask ourselves whether traditional goals have to be changed with the advancement of new technologies. Consumer welfare is still relevant, but with certain modifications. The existing concepts will have to be redesigned to reflect the current values.

Currently, it is crucial to include all consumers into consideration. Every platform user may be affected by competition violations. It means that in the digital environment end-users, as well as undertakings, may be influenced by competition harm (consumers acting as part or outside of their commercial activities). The difficulty potentially lies in demonstrating the existence and in quantifying consumer harm.

Digital ecosystems created in the digital world display certain particularities. The issue of market power might be different from the "traditional" definitions, as in some circumstance's platform provider can be the "unavoidable trading partner". The situation is described as the "intermediation power". ${ }^{19}$ Traditionally, market power is measured by market shares. Here, a concept of market share is not useful. In the digital market, there are numerous parameters besides market power that could be relevant. ${ }^{20}$

\footnotetext{
18 See: Pošćić, A.: Europsko pravo tržišnog natjecanja i interesi potrošača, Zagreb, 2014, p. 46 and further.

19 Competition policy for the digital era, p. 4

20 Ibid., p. 50.
} 
Consumer must sense quantifiable benefits from digitalization and innovation. The innovative open market will be developed so that every actor can profit from it. Consumer welfare must be maximized. Free functioning of the market ensures consumer choice and confidence. The new market encourages producers to constantly offer new or improved products and services. It is not enough to offer a variety of products but also to innovate and offer new products. Innovative techniques are used to offer new technologies and deploy new marketing strategies. Undertakings are under constant pressure to invest in new technologies and to adapt their business process to new circumstances. ${ }^{21}$

\section{DEFINITION OF THE RELEVANT MARKET IN THE DIGITAL ERA}

Digitalization affects market structure and entails specific competition concerns. There are many new notions to be discovered and understood, such as disruptive innovation, big data, algorithmic collusion, two-sided markets, market power, network effects. We have already mentioned that so far competition authorities were reluctant to consider the innovation aspects in their assessment. The traditional static examination has been centered around prices and their consequences on consumer harm, instead of on innovation concepts.

The definition of the relevant market is one of the main elements in competition assessment. ${ }^{22}$ It is the first step in any market evaluation and it is sometimes called "market screen". The novelty is that we have multi-sided markets with two or more sets of users where platforms can effectively cross-subsidize between different categories of end-users. It is usually the situation where one consumer receives a product for free and the other pays for it. In that situation, SSNIP ("small but significant and non-transitory increase in price") test ${ }^{23}$ may be too simple and not adaptable to multi-sided markets. Using the old test would probably result in defining markets too narrowly. The SSNIP-test takes in consideration only the existing products and examines if the increase of existing prices of 5-10\% would encourage consumer to switch to other products. The two- and multi-sided markets complicate the picture. As long as there

\footnotetext{
${ }^{21}$ Marcos, F.: Innovation by dominant firms in the market: damned if you don't... but damned if you do? in Nihoul, P., Van Cleynenbreugel, P. (eds.): The Roles of Innovation in Competition Law Analysis, Cheltenham, 2018, p. 35.

22 See Whish, R., Baily, D.: Competition law, ninth edition, Oxford, 2018, p. 26 and further., Pošćić, A. : Europsko pravo tržišnog natjecanja i ekonomija dijeljenja, Zbornik Pravnog fakulteta Sveučilišta u Rijeci, 40 (1) 2019, p. 249 and further.

23 Van den Bergh, R., op.cit., p. 142 and further.
} 
is certain competition on the market, the regulators have to be careful. Digital companies usually redefine the boundaries of markets.

Filistrucchi makes a distinction between two-sided non-transaction markets and two-sided transaction markets. The first does not have transactions between two sides of markets and the per-transaction fee is not possible. Those are mostly media markets. On the other side, transaction markets, e.g. payment cards, have a lot of transactions between the two groups of users and usually, the platform charges fees for joining and using the platform. In the situation of transaction markets, there should be only one relevant market. On the other side, in non-transaction markets products from one market may not compete with products from other markets. ${ }^{24}$

The traditional SSNIP-test looks only at existing products, without taking into consideration future products. It requires analyzing substitutes between all existing products. This test is suitable for static market, whereas in new dynamic markets there is a constant flow of new products that change the degree of substitutability between them. ${ }^{25}$

Today, a market assessment still "suffers" from not observing non-price elements. Traditionally, too much weight is on the price, but in the digital world, the user can receive more advantages in joining network with free products. As we mentioned before, consumer in the widest possible meaning should be considered. Network effects and other peculiarities of the market might have a consequence of defining the market more broadly. The Commission's attitude is conservative, in this respect. The traditional tools are still widely applied. The free products should be taken into consideration, as well as the interdependence of consumers in multi-sided markets. The dynamic assessment should be promoted.

The way we approach the definition of the relevant market will have an impact on the finding of possible market power. The digital revolution challenges the standard definition of the relevant market. Presently, we are witnessing dynamic markets under the constant evolution. The idea is based on the Schumpeterian thinking of dynamic and innovative markets under constant pressure of unexpected innovations. ${ }^{26}$ Usually, the definition of the relevant market is more or less focused on the product definition of the relevant market, where product

24 See: Copobianco, A., Nyeso, A.: Challenges for Competition Law Enforcement and Policy in the Digital Economy, Journal of European Competition Law \& Practice, 9 (1) 2018, p. 24.

25 Kerber, W., op. cit., p. 36.

26 Robertson, V.: Delineating Digital Markets under EU Competition Law: Challenging or Futile? The Competition Law Review, 12 (2) 2017, p. 132. 
differentiation may develop problems in the determination of substitutability. ${ }^{27}$ It is really difficult to define the market in dynamic industries with so many products partly substitutable. ${ }^{28}$ Today we have multi-sided markets that have to be assessed together. Probably a broader definition will be a better solution, so in that way, we could avoid too much enforcement that can have an adverse impact on innovation and consequently consumer welfare. ${ }^{29}$ Many issues need to be resolved in defining digital markets.

The market delineation is tricky when we have differentiated digital products. The Commission has so far hesitated to give strict guidelines in this respect. We do not have an established test for defining the relevant market in the new digital era. Online advertising is one example. The Commission has not decided if the online and offline advertisement markets are one broad market or separate, whether mobile and online ads are the same market, as well as whether non-search and search-based ads are part of the same market. ${ }^{30}$

One decision that might suggest of Commission's shift in slowly considering other parameters is the famous Google Shopping case. In 2017, the Commission found that Google has abused its dominant position in the general online search market by giving an illegal advantage to its own comparison shopping service. ${ }^{31}$ It is the first case in which the Commission assessed algorithmic manipulation that may violate competition. ${ }^{32}$ Some scholars see this as a paradigm shift, ${ }^{33}$ as it might suggest that the Commission is changing its policy towards the protection of non-price competition in new digital markets. ${ }^{34}$ Before, the Commission has disregarded other market concerns. For this part of the assessment, it is interesting to see the way the Commission defined the relevant market as one that encompasses general search services. It is the market where users do not pay for services, but "pay" with their data. Before, the Commission did not consider free markets at all. ${ }^{35}$ Here, we have an exchange of a service for data. ${ }^{36}$ The Commission distinguished two separate product

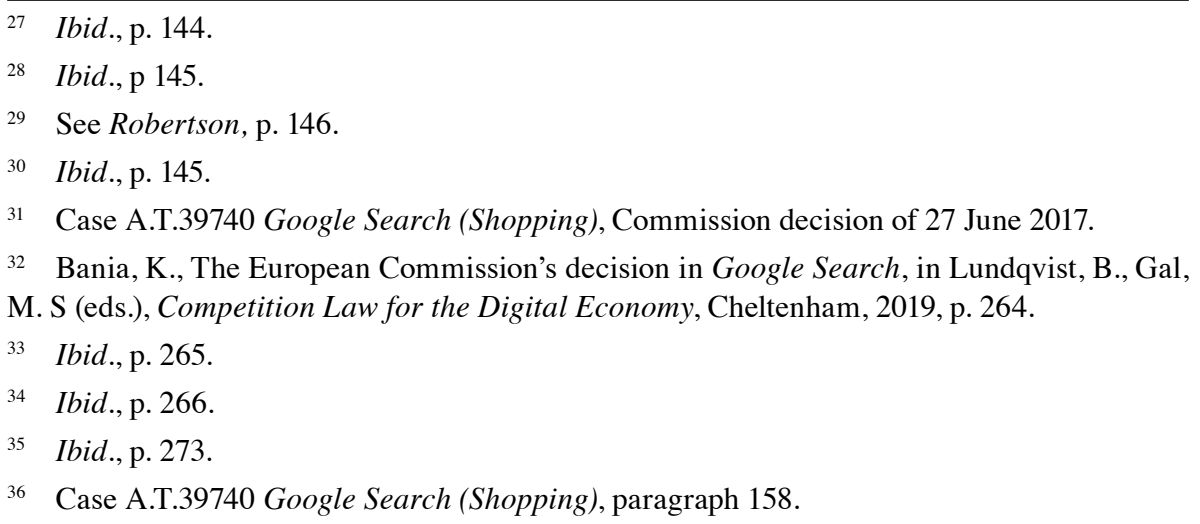


markets: the general search engines and social networking. ${ }^{37}$ The proof that the Commission takes other parameters can be seen from the wording: "..... even though general search services do not compete on price, there are other parameters of competition between general search services. These include the relevance of results, the speed with which results are provided, the attractiveness of the user interface and the depth of indexing of the web." ${ }^{38}$

According to Bania, the Commission did not explain two issues. First, the Commission failed to identify advertising markets as those affected by discriminatory abuses. The second issue concerns the lack of precise explanation of taking the free products market into consideration. The Commission did not indicate precisely why the market for the provision of general search results was considered to be the relevant market. ${ }^{39}$

As it can be observed, there is a need for some change in the future Commission's assessment, although some slow steps have been taken. We find useful recommendation given by Robertson. She suggests taking into consideration the market side, where revenues are generated, but also on the other side, where services are provided for free. The constant dynamic characteristic of the market should always be taken into consideration. If necessary, the relevant market has to be redefined. The digital markets are quite distinguished and exposed to fast innovation with a short duration. That is why the market should not be defined narrowly. The online /offline paradigm is sometimes left aside, but she suggests taking into consideration also offline pressures in defining the substitutability. She urges for a more important position of innovation in every competition analysis. ${ }^{40}$

Innovation is regarded as an important element in future competitive markets. Traditional static concepts of competition tools will have to be improved and adapted to the new reality. There is a consensus that innovation is welcome in competitive markets. The problem is with static concepts of competition tools that until now have been ignoring innovative concepts.

Market definition is not an end, but only the first step in competitive assessment. The future will be to use a "more innovation specific assessment approach", in other words, a test that takes into consideration research and development. ${ }^{41}$

\footnotetext{
37 Google Search (Shopping), paragraph 179.

38 Google Search (Shopping), paragraph 180.

39 Bania, K., op. cit., p. 280.

40 Robertson, V., op. cit., p. 151.

${ }_{41}$ Kerber, W., op. cit., p. 47.
} 


\section{APPRAISAL OF MARKET POWER IN THE DIGITAL ERA}

Market power in the digital environment might prove to be different than in traditional markets. Digital markets have some peculiarities that distinguish them from traditional markets. One is a large amount of data. Possessing and controlling market data may be one of the key components in determining the firm's market power, although we are not convinced that competition agencies are taking them into consideration. Google Shopping case might suggest a change in direction. One of the criteria that were determinative in establishing Google's dominant position was that a significant number of consumers trust the relevance of search results provided by Google and are unlikely to multi-home, even if Google were to degrade the quality of its general search service. ${ }^{42}$ It is one of the pieces of evidence showing that the Commission is slowly taking into consideration parameters other than price, such as quality-related concerns ${ }^{43}$ Platforms may take a lot of different roles: as intermediaries, as collectors of consumers' preferences, as suppliers, but also as providers of certain services. Possessing a large amount of data allows them to make informed decisions. In every industry, there is an increase in the amount of data. ${ }^{44}$ Data are included in the value chain and change a traditional paradigm to data and innovation-driven firms. ${ }^{45}$ It enables platforms to provide better services and at the same time attract new users.

When one firm becomes a data-driven winner, it automatically becomes the system leader. The suppliers are locked. Examples are Google and Amazon. ${ }^{46}$ Data has become a critical resource in competition law, and it is necessary to explore how it should be taken into consideration.

The term that is more and more used is data innovation. Besides data, there is a lot of other factors that have to be taken into consideration, such as network effects, market tip in favor of one firm, high-quality data, and predictive modeling tools ${ }^{47}$ Some platforms may offer access to other users in an arbitrary or even discriminatory way.

\footnotetext{
42 Google Search (Shopping), paragraph 312.

43 Bania, K., op. cit., p. 283.

44 Lundqvist, B., Regulating competition in the digital economy, in: Lundqvist, B., Gal, M. S (eds.), Competition Law for the Digital Economy, Cheltenham, 2019, p. 10.

45 Ibid., p. 11.

46 Loc. cit.

47 Ibid., p. 12.
} 
There are many undertakings with a strong market concentration in the digital economy. ${ }^{48}$ Network effects play a significant role in digital markets. They operate in a way that the more users it attracts, the network becomes more attractive for other users. The quality of services also increases. The dilemma is whether this concentration should be condemned by competition authorities. In the digital economy, every company wants to gain a new market. The value of the platform increases as more and more people use it. One company becomes the winner of the market and a gatekeeper. It is important to be the first, not the best. ${ }^{49}$ The firms endeavor to take the leading position in the early development of a particular technology.

One phenomenon is especially evident here. It is the "winner takes it all" that prevails. On the other hand, the market power of one undertaking may be of short duration, as the changes are very fast. Markets in the digital economy have certain characteristics that distinguish them from others: more vigorous competition "for" the market, than "in" the market, network effects, multi-sided markets, innovative markets, protection of intellectual property rights, and big data. ${ }^{50}$ It means that there is the vigorous competition to enter the market and replace the dominant platform.

Market power will be difficult to determine. It is extremely important not to condemn every undertaking in a leading position with inventive products. The changes in the new economy are quick. The dominant position is not prohibited, but its abuse is. The main concern is not to condemn the dominant firm as the one that violates competition law only because it produces innovative and different products and services.

The traditional tools for the assessment of market power could be inadequate. High market share as the main criterion in the determination of market power must be combined with other indicators, as some services are offered for free and some firms do not have a high market share for a long time. ${ }^{51}$ The competitive constraints from buyers and sellers should also be taken into consideration. Market power, as well as the definition of the market, is exposed to constant change. There are suggestions in favor of data gathering

\footnotetext{
48 Zimmer, D.: The digital economy: a challenge for competition policy?, in: Nihoul, P., Van Cleynenbreugel, P. (eds.): The Roles of Innovation in Competition Law Analysis, Cheltenham, 2018, p. 299.

49 Schmidt, H. K.: Taming the shrew: is there a need for a new market power definition for the digital economy?, in Lundqvist, B., Gal, M. S (eds.), Competition Law for the Digital Economy, Cheltenham, 2019, p. 57.

50 Ibid., p. 44.

51 Copobianco, A., Nyeso, A., op. cit., p.24.
} 
and data analytics as indications of market power. Data has become a valuable asset. ${ }^{52}$

The market power must be assessed by analyzing the specific service that the platform provides. The Commission thinks that leading platforms should act as regulators of the ecosystems and networks with special responsibility. The protection of competition for the market becomes essential, with dominant platforms behaving as "regulators". It means that they establish certain rules of interaction while maintaining fair and undistorted competition on their platforms. ${ }^{53}$

Despite general characteristics, platforms are heterogenic, and every situation will have to be assessed independently.

We have already stressed that market shares are not an appropriate tool in the digital economy as an undertaking's high market share can be very fragile. It is probably the right time to abandon too much reliance on market share. ${ }^{54} \mathrm{Ac}$ cording to the Commission's praxis, a substantial market share is seen as one of the indicators of a dominant position. Of course, the Commission always stressed that high market share is not the only factor and its importance varies from market to market according to its structure. ${ }^{55}$ Commission has also been focused on the time scale and the position of other competitors on the market. ${ }^{56}$

The collection and commercial use of data pose competition considerations as we are facing even more competition between firms. Previously, the public authority has been the only collector of data. The problem is that until now they had no interest in storing and collecting them. Gradually, data has been marketed to consumers and firms. Following Google, Amazon, and Facebook, private entities started collecting and storing large amounts of personal and non-personal data. ${ }^{57}$ Collecting data has become profitable as firms realize that possession of personal and non-personal data might give them a competitive advantage. With necessary data and with the "help" of algorithms they might focus their products or services on the targeted group of consumers. Today we are speaking of competition for and with data. ${ }^{58}$

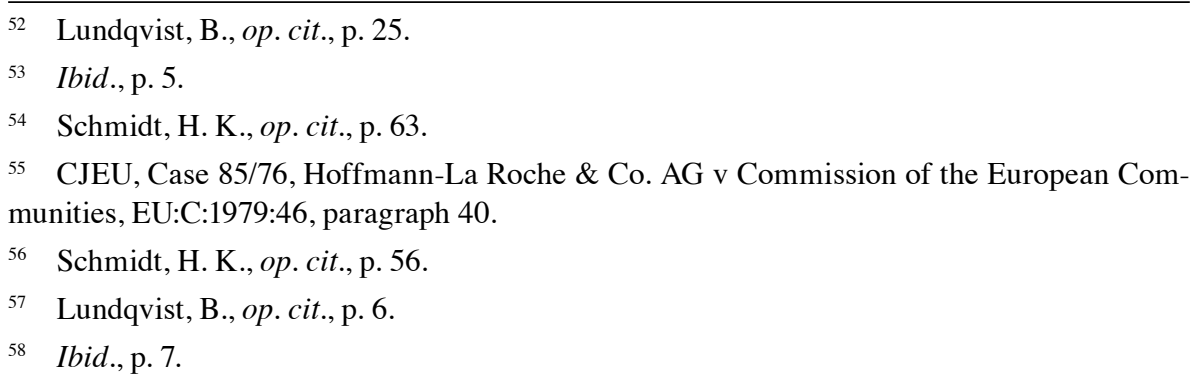


System leaders might act as gatekeepers and collectors of data not giving access to other business users in the ecosystem. Other brick-and-mortar firms will try to compete with leading gatekeepers, but it will be difficult as they collect and control all the incoming data. The only way for the "old firms" to survive is to become innovative and to collaborate in joint platforms. Another peculiarity of digital markets is "tipping". It is a situation in which the leading platform can increase its market share through network effects and rise to a position that is almost invulnerable to competition. The system leader can act as "winner takes it all or most" and becomes the ruler of the ecosystem. ${ }^{59}$

If we have an innovative high-tech leading firm, it doesn't automatically mean it is a monopolist. Even if it is in a dominant position, it will be of no relevance if the admission of new competitors is free. ${ }^{60}$ The definition of a dominant position and its assessment has been developed in the Court's case law. In the case of United Brands ${ }^{61}$ and Hoffman la Roche, the dominance has been defined under EU law as a position of economic strength enjoyed by an undertaking, which enables it to prevent effective competition from being maintained on a relevant market, by affording it the power to behave to an appreciable extent independently of its competitors, its customers and ultimately of consumers. This means that the undertaking's decisions are largely indifferent to the other actions. Those elements are still relevant in the digital era. Some authors criticize the criterion of independence as not fit for the digital era. The reason is that no one can stand alone and act independently. Another point for debate is the ability to increase prices due to their independent position. In the digital environment, there can be other abuses not connected to price increases.

In the digital environment, the paradigm "winner takes it all" or "snowball effect" is true as when an undertaking reaches the "tipping" point while having a large number of users, it attracts more and more customers. Here, we have a few firms with a strong market position. Personal data present a strategic value as platforms combine data from multiple platforms and the operator can optimize the products for end-users. We are facing more competition for end-users than in traditional markets. The operators create multiple platforms that can connect user's data with them with the improved service. Large platforms possess a large amount of data and can control new entrants. It would be the same if they possessed advanced technology. Here the term 'competition for the market' is true, as problems with leveraging can raise concerns. We

59 Ibid., p. 9.

60 Marcos, F., op. cit., p. 43.

61 CJEU, Case 27/76, United Brands Company and United Brands Continental BV v. Commission, of the European Communities, ECLI:EU:C:1978:22, paragraph 65. 
have competition for the market and especially competition for more than one market. $^{62}$

With multi-sided platforms, the competition for more than one market can occur, as the leading position of one market operator can allow the leveraging market position to other markets. In this sector the interconnection and the building of the ecosystem are relevant. Firms compete on multi-sided platforms and can amplify their power to other connected markets. Those markets are vulnerable. Undertakings with significant market power may sometimes be under pressure for innovation from other firms and their position may overturn.

The specificity is that products are sometimes given for free in exchange for personal data. This can be connected to the zero-price effect where consumers opt for free products instead of opting for products for which they pay and are of better quality. The textbook example is one in which you will receive free shipping if you decide to buy products exceeding a certain amount. ${ }^{63}$ It is a situation where one side of the platform subsidizes the other side of the platform. The platform gains certain advantages even in that situation. The exchange is usually in the form of data. Consumer data are seen as a non-monetary form. ${ }^{64}$ It only means that the traditional definition of market power may not be suited for the digital economy. The concept of dominance should be flexible enough to cover all possible solutions in the market.

\section{CONCLUSION}

In this paper, we have tried to shed some light on the future of competition policy in the new digital era. The idea was to offer possible directions for the understanding of the position of innovation in competition assessment. Some can find competition policy too slow, not able to respond to the fast developments and innovations. A dynamic approach would help in a faster and smoother adaptation of competition rules to new improvements. In order to foster a dynamic approach, it is necessary to understand competitive forces underpinning developments, so it is possible to distinguish normal from disruptive behavior. As already mentioned, too much regulation can be problematic, as it might stifle new ideas. Also, the self-adaption of new markets should not be underestimated.

62 Copobianco, A., Nyeso, A., op. cit., p. 23.

63 Schmidt, H. K., op. cit., p. 53.

64 Competition policy for the digital era, p. 44. 
It is important to insist on clarity. The new paradigm is not needed. There is a necessity to reinterpret the existing rules and apply them to new situations. The regulators will have to improve their capabilities and try to understand new technology. Despite the need to invest in education, innovation is usually unpredictable. As Kerber rightly points out, we still have very poor knowledge about innovation processes in markets. ${ }^{65}$

It is important to develop tools that are in line with traditional competition goals; consumers and end-users. We believe that the analysis of the market and possible market power could be a good starting point for the protection of future competitive markets. The dynamic assessment could enable the development of new definitions and notions. The doctrine advises a wise and cautious approach. ${ }^{66}$ The enforcers should shift slowly from price-fixing abuses and market sharing to including innovation in the analysis. As always, the right balance between promoting and controlling innovation should be maintained.

Last, but not less important, is the proposition to enhance cooperation between competition and data protection authorities. It is an unknown part of data-driven economy. Data are becoming valuable competition law resources.

\section{LITERATURE}

1. Bania, K.: The European Commission's decision in Google Search, in Lundqvist, B., Gal, M. S (eds.), Competition Law for the Digital Economy, Cheltenham, 2019 -DOI: https://doi.org/10.4337/9781788971836.00018

2. Bodiroga-Vukobrat, N., Pošćić, A, Martinović, A.:, "Old Economy" Restrictions in the Digital Market for Services, InterEuLawEast, V (2) 2018, pp. 169-188

-DOI: https://doi.org/10.22598/iele.2018.5.2.6

3. Copobianco, A., Nyeso, A.: Challenges for Competition Law Enforcement and Policy in the Digital Economy, Journal of European Competition Law \& Practice, 9 (1) 2018, pp. 19-27

-DOI: https://doi.org/10.1093/jeclap/lpx082

4. Crémer, J. et al: Competition policy for the digital era, final report, Luxembourg, 2019

5. Kerber, W.: Competition, Innovation and Competition Law: Dissecting the Interplay, in Gerard, D. et al. (eds.), Dynamic Markets, Dynamic Competition and Dynamic Enforcement, Bruxelles, 2018

-DOI: https://doi.org/10.2139/ssrn.3051103

65 Kerber, W., op. cit., p. 49.

66 Marcos, F., op. cit., p. 49. 
6. Lundqvist, B.: Regulating competition in the digital economy, in: Lundqvist, B., Gal, M. S (eds.), Competition Law for the Digital Economy, Cheltenham, 2019 -DOI: https://doi.org/10.4337/9781788971836

7. Marcos, F.: Innovation by dominant firms in the market: damned if you don't.... but damned if you do?, in Nihoul, P., Van Cleynenbreugel, P. (eds.): The Roles of Innovation in Competition Law Analysis, Cheltenham, 2018

-DOI: https://doi.org/10.4337/9781788972444.00011

8. Pošćić, A.: Europsko pravo tržišnog natjecanja i ekonomija dijeljenja, Zbornik Pravnog fakulteta Sveučilišta u Rijeci, 40 (1) 2019, pp. 237-260.

-DOI: https://doi.org/10.30925/zpfsr.40.1.9

9. Pošćić, A.: Europsko pravo tržišnog natjecanja i interesi potrošača, Zagreb, 2014

10. Robertson, V.: Delineating Digital Markets under EU Competition Law: Challenging or Futile? The Competition Law Review, 12 (2) 2017, pp. 131-151

11. Schmidt, H. K.: Taming the shrew: is there a need for a new market power definition for the digital economy?, in Lundqvist, B., Gal, M. S (eds.), Competition Law for the Digital Economy, Cheltenham, 2019

-DOI: https://doi.org/10.4337/9781788971836.00010

12. Stucke, M. E., Grunes, A. P.: Big Data and Competition Policy, Oxford, 2016

13. Van Cleynenbreugel, P.: Innovation in competition law analysis: making sense of on-going academic and policy debates, in Nihoul, P., Van Cleynenbreugel, P. (eds.): The Roles of Innovation in Competition Law Analysis, Cheltenham, 2018 -DOI: https://doi.org/10.4337/9781788972444

14. Van den Bergh, R.: Comparative Competition Law and Economics, Cheltenham, 2017

15. Zimmer, D.: The digital economy: a challenge for competition policy?, in: Nihoul, P., Van Cleynenbreugel, P. (eds.): The Roles of Innovation in Competition Law Analysis, Cheltenham, 2018

-DOI: https://doi.org/10.4337/9781788972444.00023

16. Whish, R., Baily, D.: Competition law, ninth edition, Oxford, 2018

-DOI: https://doi.org/10.1093/law-ocl/9780198779063.001.0001 
